\title{
NEW ADVANCES IN THE INSPECTION OF FLARE STACKS
}

Carlos Martín-Díaz de Espada*** Holder of a doctorate in Industrial Engineering from the University of Cadiz and a degree in Industrial Engineering from the University Carlos III of Madrid.

María Dolores Rubio-Cintas* Holder of a doctorate in Industrial Engineering from the University of Malaga and a degree in Industrial Engineering from the University of Cadiz.

*UNIVERSITY OF CADIZ Higher Polytechnic School of Algeciras. Dept. of Industrial Engineering and Civil Engineering. Avda. Ramón Puyol, s/n - 11202 Algeciras (Cadiz). Tel. +34956028000.

mariadolores.rubio@uca.es // carlos.martin@uca.es

**LA LINEA VERTICAL Camino de la Ermita 10-C5 - 11300 La Línea (Cadiz). Tel. +34 956 763055. cmartin@lalineavertical.com

\section{CODIGO DYNA = 3310.04}

\section{OVERVIEW}

Flare stacks are a key element in the safety of petrochemical and refinery industries; the correct operating conditions thereof must be ensured through a schedule for the periodic reviewing of all parts thereof. Advances in Non-Destructive Testing (NDT) in recent years and the application thereof to this field allow reliable, objective information to be obtained. This article describes and groups together the main applicable NDT techniques, analysing their advantages and disadvantages, updated with the new possibilities offered by unmanned aircraft or drones.

KEY WORDS: flare stack, non-destructive testing, inspection, guy wires, drones

\section{INTRODUCTION}

Industrial flare stacks are key mechanical components in the complex system designed for the safe, reliable and efficient discharging and combustion of hydrocarbons generated in the safety discharges by the processing units of petrochemical plants [1]. At the same time, we know that these installations suffer significant deterioration due to the high temperatures, chemical aggressiveness of the gases they expel and unfavourable climate conditions. As they must be permanently available and operational during any emergency situation occurring at the plant throughout their 
projected useful life, flare stacks must be inspected regularly with regular maintenance. Due to the critical nature of this equipment, the time available for the inspection thereof tends to be scarce ( 4 or 5 days).

\section{TYPES OF FLARE STACK}

Flare stacks are classified into three main groups [1, 2 and 3]: Elevated, horizontal and enclosed-flame flares. We will focus on the first group, which in turn is subdivided into:

I. Self-supported flare stacks, with a smaller affected surface area, suitable for heights of up to $76 \mathrm{~m}$ and with a low manufacturing cost (photo 3 ).

II. Supported using guy wires or cables, greater affected surface area of ground, heights of up to $180 \mathrm{~m}$ and average manufacturing cost (photos 1 and 4).

III. Supported by a permanent (photo 5) or temporary (photo 6) metal tower (derrick-supported). Small affected surface area, heights of over $200 \mathrm{~m}$ and high manufacturing cost. Mentioned separately, although this group would also have to include flare stacks for offshore platforms.

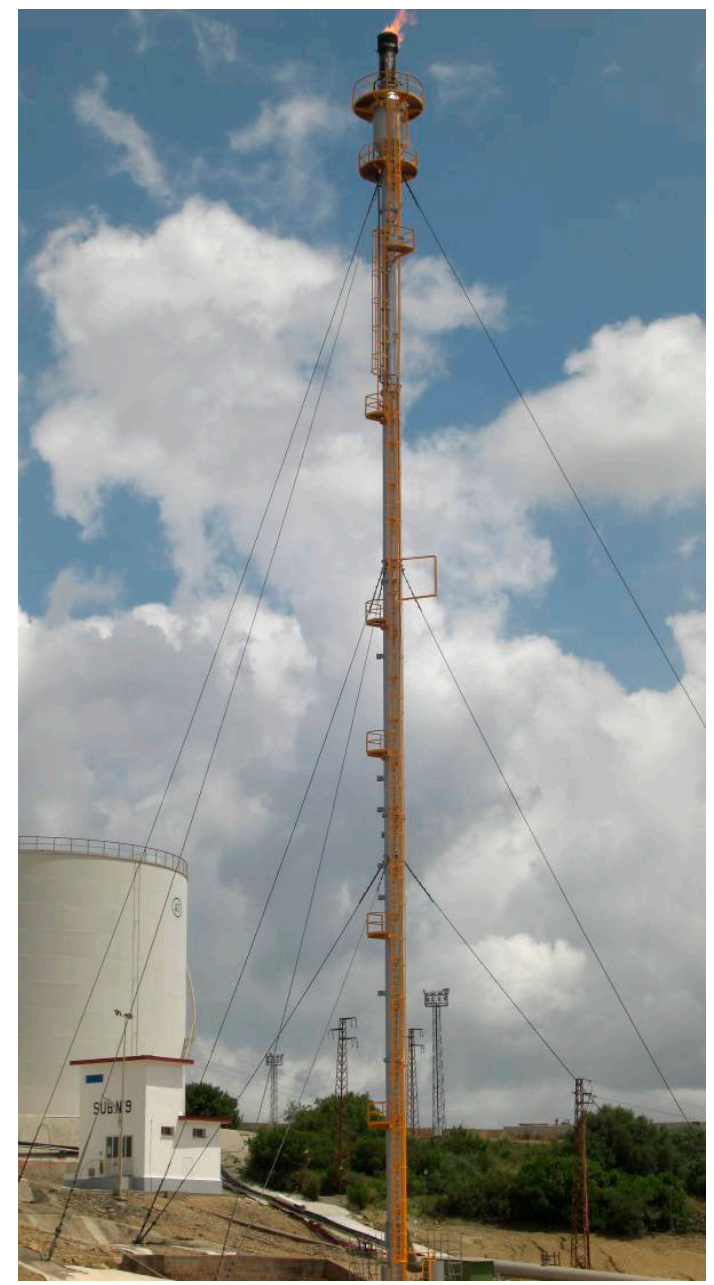


Photo 1: General view of a typical flare stack supported using guy wires

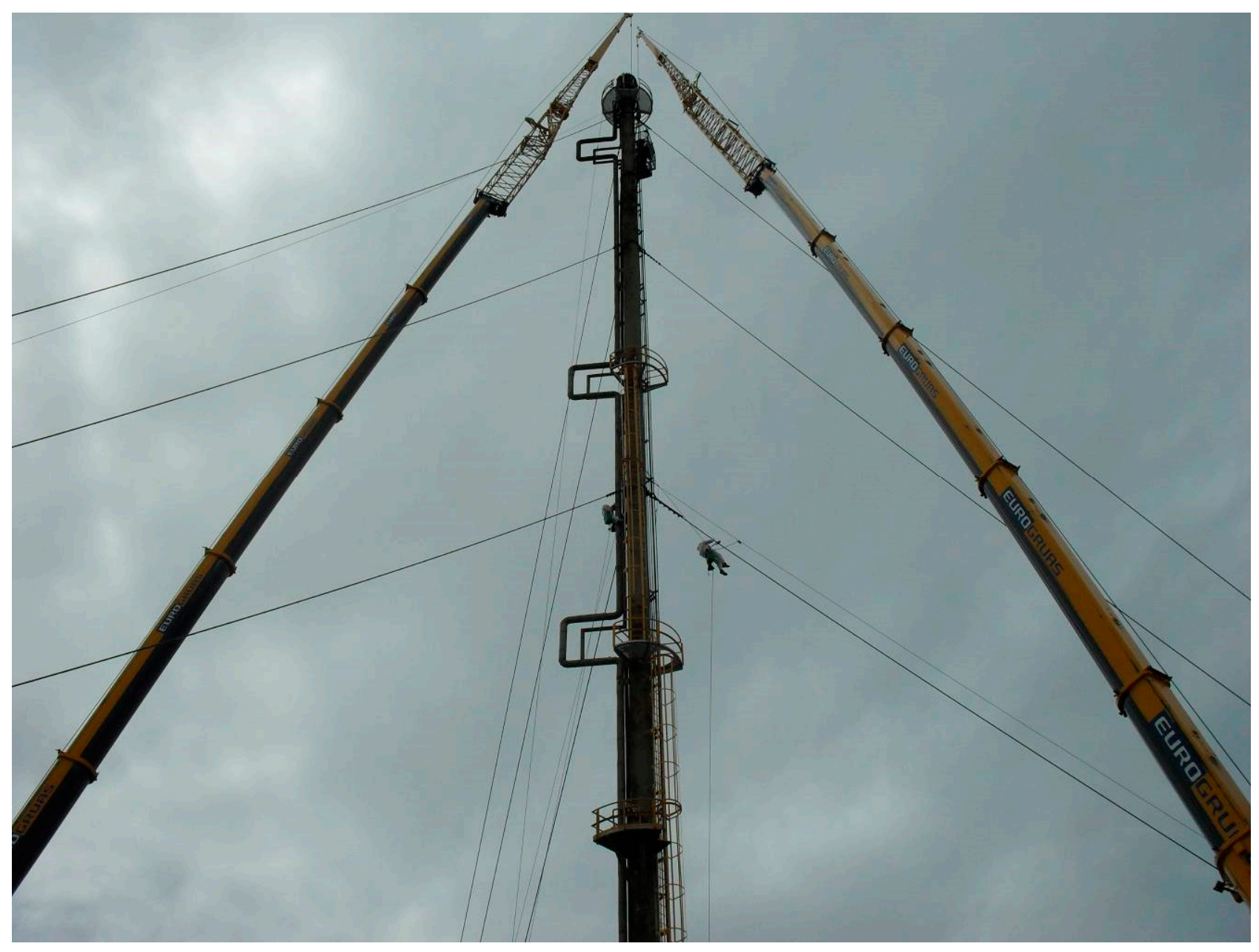

Fig. 02 Works on a flare stack using cranes and baskets, combined with rope access techniques for the inspection and lubrication of guy wires 


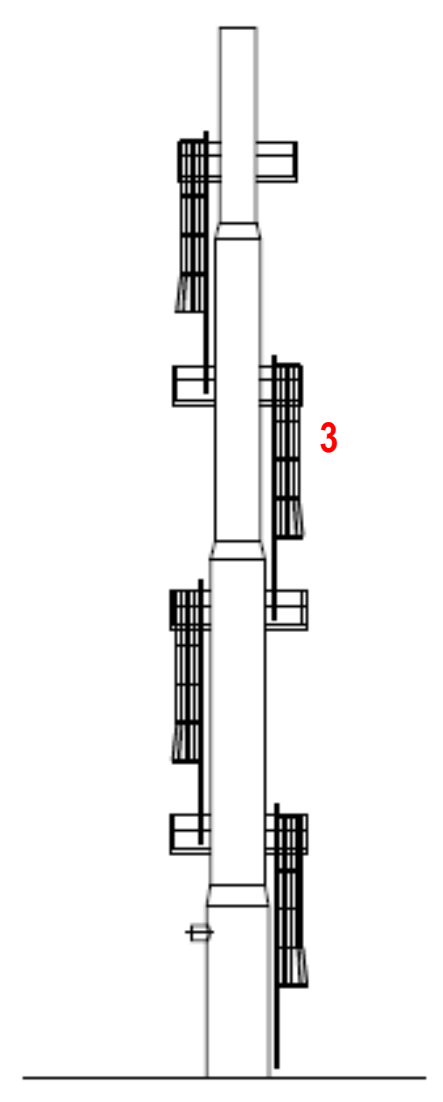

Types of elevated flare stack [6]

3. Self-supported

4. Supported using guy wires

5. Supported using a permanent derrick

6. Supported using a temporary derrick

6

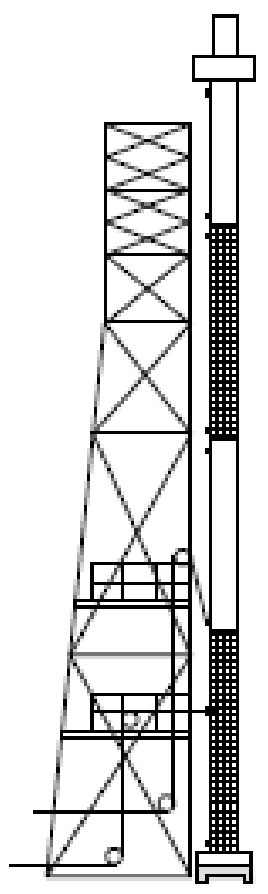

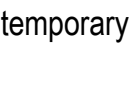

4

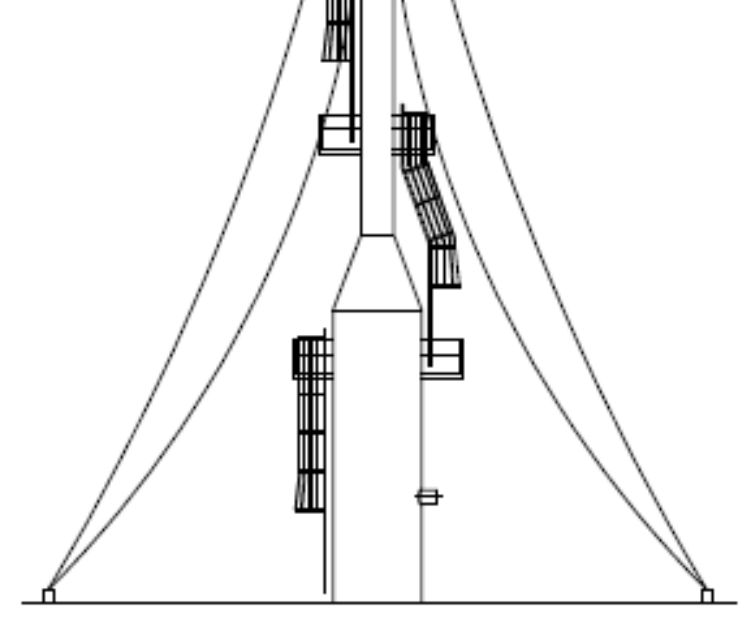

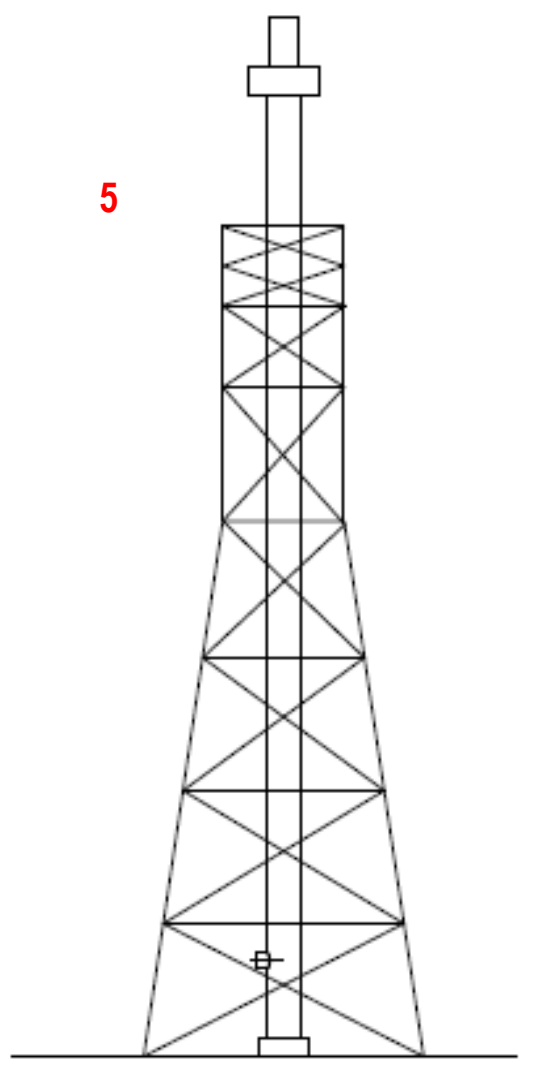




\section{MAIN PARTS OF A FLARE STACK}

Flare stacks can be divided into three main parts: the seal, shaft and burner. The seal is the bottom part, where the gas comes in and, when there is enough pressure, passes through the water barrier that retains it and travels up the shaft to the burner. The shaft, the central part of the flare stack, connects the seal to the burner. It is normally cylindrical with wall thicknesses of $8 \mathrm{~mm}$ to $20 \mathrm{~mm}$. Finally, the gases are burnt in the burner; for this purpose there is always a pilot flame burning awaiting potential discharges of gas from the network the flare stack is connected to.

\section{DEFINITION OF AREAS FOR INSPECTION}

Following the performing of any inspection, one of the key elements is unequivocally identifying any faults found in each area inspected. It is particularly difficult to describe the location of faults in flare stacks, as the points of reference are very similar; this is normally done by indicating fault locations according to the orientation of North, South, East or West and height from the ground. But for type II and III flare stacks it is also possible to:

- Divide the flare stack into areas (1-2-3-4), coinciding with the orientation of the wires (generally three every $120^{\circ}$ ) or the pillars of the support structure (generally 4 every $90^{\circ}$ ).

- From the main gas entrance flange, each orientation can be numbered from 1 to 4 in a clockwise direction.

- From the ground to the top, each level of anchorage points (of guy wires or to a structure) can be numbered correlatively; 1,2 , 3, etc.

- Finally, each anchorage point can be assigned two digits, the first to indicate the orientation and the second the level of anchorage, for example, "anchorage 2-4" (the second in a clockwise direction from the gas entry point and the fourth in terms of height). This method allows the flare stack to be easily sectioned and avoids errors through the use of compasses in areas with possible interference from magnetic fields (photo 7). 


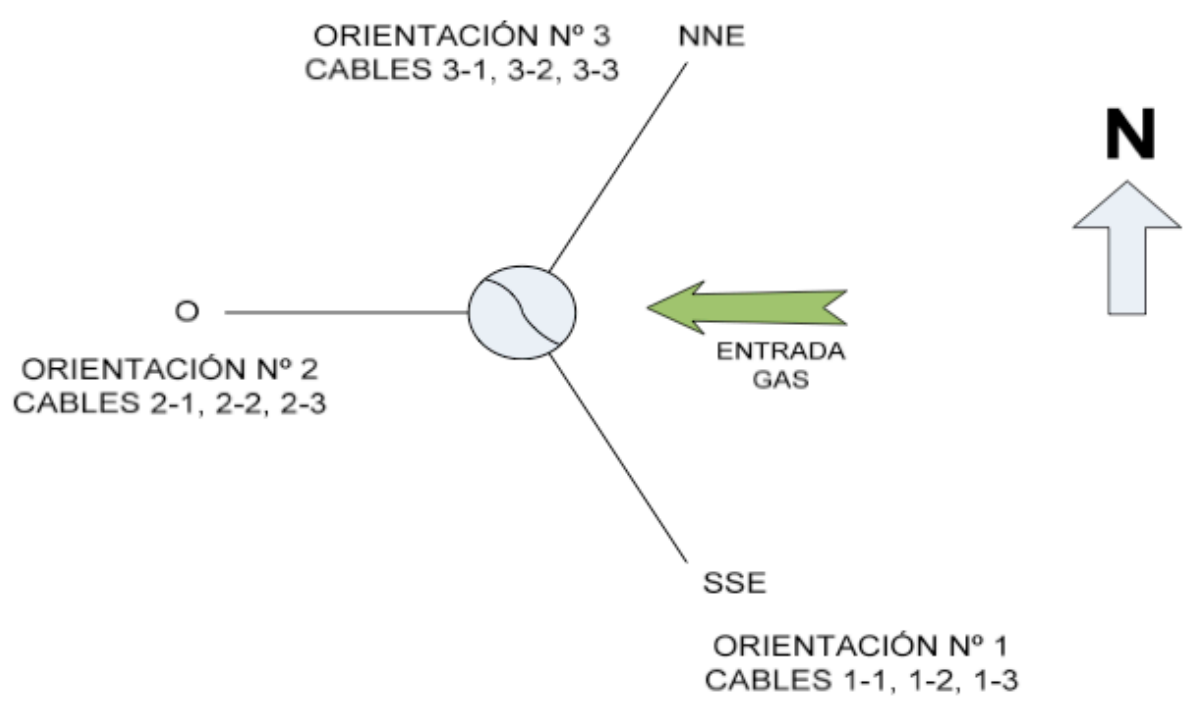

Photo 7: Terminology diagram of a flare stack with 9 guy wires in 3 orientations and on 3 levels

\section{CURRENT INSPECTION SYSTEMS, MEANS OF ACCESS}

Inspections of installations as particular as chimneys or flare stacks will be performed $[4,5,6,7,26]$ based on pre-established and correctly planned systems (except in the case of urgent inspections following faults, accidents, etc.); the reason for planning and studying the work is two-fold: on the one hand, the limited duration of the inspection time (this will generally coincide with a scheduled stoppage) and on the other, the considerable difficulty of access, also restrict the auxiliary means that can be used. Inspectors currently use the following procedures to access flare stacks:

- Traditional access, using the existing ladders and platforms.

- Installation of tubular scaffolding around the flare stack.

- Use of rope access techniques [8].

- Use of telescopic elevation platforms or baskets supported by cranes.

- Use of drones

Traditional access is not especially difficult beyond the difficulties of installations of great height that are very affected by weather conditions. In any case, as these installations require very infrequent access (normally during stoppages and every 5 years), personnel specialising in rescue/evacuation and visual inspection must gain access at least once beforehand to confirm the condition of the ladders, platforms and structure, so that other NDT technicians may proceed with their work. The main 
problem with this traditional access is the limitation of the areas to be inspected, these being only those accessible from ladders or platforms, representing no more than $40 \%$ of the installation.

Permanent scaffolding systems are very costly and require prolonged stoppages to assemble/disassemble such; in any case they are used for small flare stacks, with heights not exceeding 40 metres, and without traditional means of access. Their main advantage is that, once assembled, it is very easy to perform the inspection work and any repairs. Tubular scaffolding is normally installed for this work; the use of suspended platforms or scaffolding is rare.

Access using rope access techniques (photo 2 ) is currently on the rise; rope access equipment, which is ever more advanced and safe, allows expert personnel to gain access to any part of the flare stack with limited means and great speed. This speed and versatility is the main advantage, the problem being the limitation in the work to be performed (this cannot involve heavy loads), but they are very useful in the case of the application of NDT. The use thereof, as well as the use of scaffolding, is regulated by European directive 2001-45-EC on "Temporary Rope Access Work" [9], in line with the requirements of the current Legislation on the Prevention of Occupational Risk [10] (European Directive 89/391/EEC).

Elevation platforms with a telescopic arm [11] or baskets supported by cranes (photo 2) are particularly useful to perform maintenance operations, for example, the replacement of the burner of the flare stack, replacement of the metal platforms or access ladders, etc. On the other hand, using them for NDT is very expensive, as the cranes have certain limitations in terms of access and reach as a result of the existence of the guy wires of the flare stack and in many cases, different ground levels around the base of the shaft.

In any of the scenarios mentioned we must highlight the importance of the inspector carrying out the work being trained and certified according to standard EN473 "Ensayos no destructivos. Cualificación y certificación del personal que realiza ensayos no destructivos. Principios generales" (Non-destructive testing. Qualification and certification of personnel who perform non-destructive testing. General principles) [12], in the corresponding field.

With the use of Unmanned Aircraft (commonly known as drones) we can reduce the access needs of inspection personnel to the installation and, overall, perform a large part of the inspection work prior to the stoppage while the flare stack is operational. 
The use of these devices does however require various authorisations issued to the operating company, which are also specific to each country [25].

\section{CURRENT INSPECTION SYSTEMS, MAIN NDT TECHNIQUES}

Within the wide range of existing Non-Destructive Testing techniques, the following can be highlighted as those of greater use in the inspection of flare stacks:

3.1 Visual inspection by people

3.2 Visual inspection using drones

3.3 Inspection using ultrasound techniques

3.4 Magneto-inductive analysis of cables

3.5 Measurement of wire tension

3.6 Performing of $x$-rays

\subsection{VISUAL INSPECTION BY PEOPLE}

All parts of the flare stack are subject to visual inspection. It is recommendable to have sheets pre-prepared for this purpose, where the faults or details found can be recorded section by section, with references to photos and the inspector's comments. An initial inspection of ladders and platforms must take place, with special attention paid to the condition of collective protection elements (railings, floors, etc.); the result of this inspection may affect the planning of the rest of the work, as the bad condition of the means of access may even lead to the aborting of the rest of the inspection. In any case, it is recommendable not to perform other NDT until the visual inspection has okayed access to the different areas of the flare stack. Following this first phase, the following critical point is the burner area or tip of the flare stack (photo 9). It is normal for the fireproof coating to come away, which tends to cause changes in the colour of the metal the burner is made of (due to the high temperatures), making a bird's-eye view essential (photos 8.1, 8.2) to detect any blocking of gas outlets, breakage or cracking of the nozzles (photo 8.3) or similar faults. Due to the difficulty involved in repairing the tip in situ (due to technical complications, means of access and the available time), many facilities have a second burner that is identical to the one installed, in perfect condition; while the flare stack is not in service, these are swapped around using cranes in order to perform maintenance on the one that was being used and leave it in perfect condition to once again swap these around during the following stoppage.

The other areas to be analysed closely are the connection flanges between the shaft sections, the guy-wire anchorage points (both on the flare stack and in the ground), the gas and steam lines that travel up to the burner, the hydraulic seal and the condensation drain pots. With some flare stack designs, it is possible to access the interior of the shaft, which is useful to be able to confirm possible internal corrosion. 


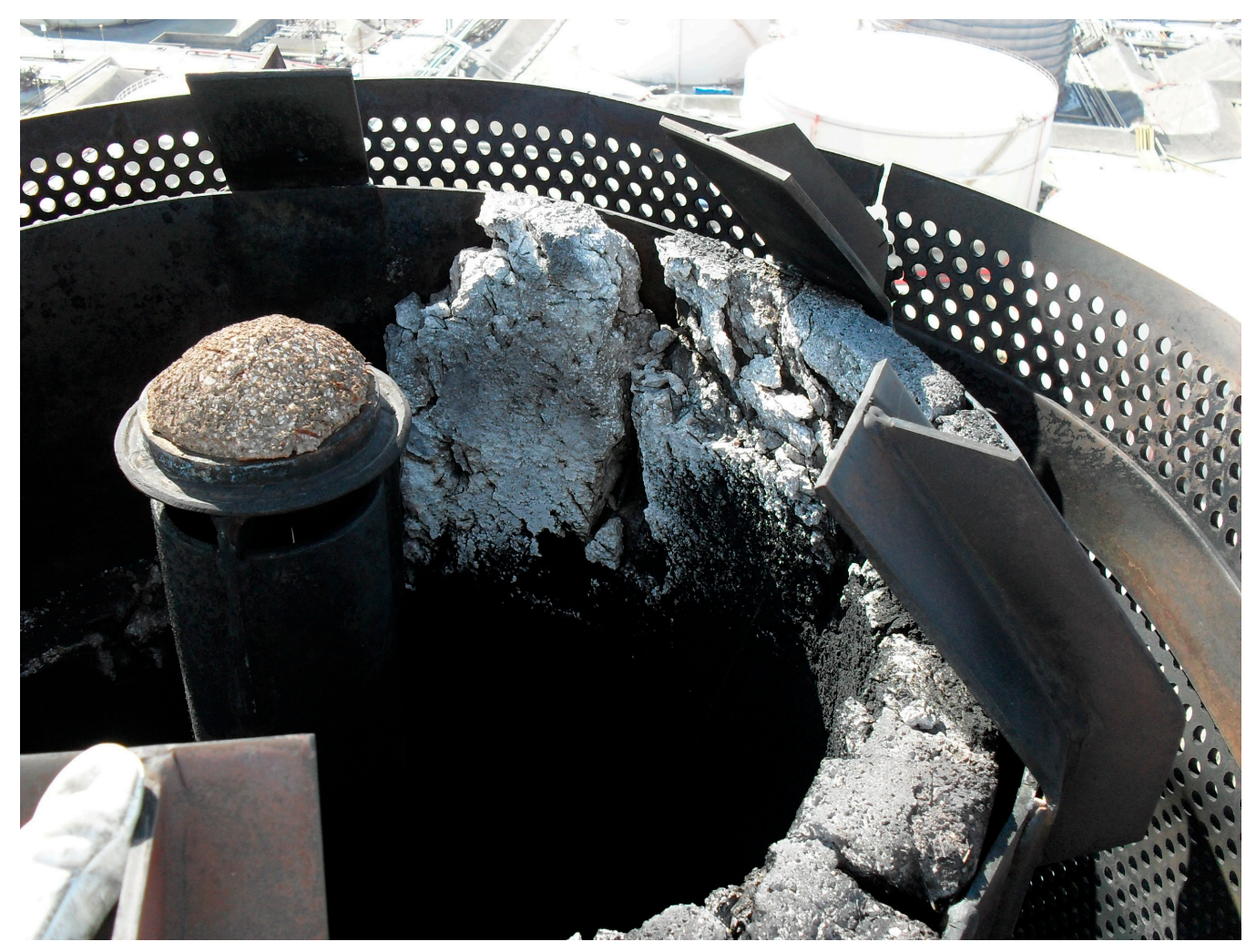

PHOTO 8.1 View from above of an installed burner, with detachment of fireproof coating 


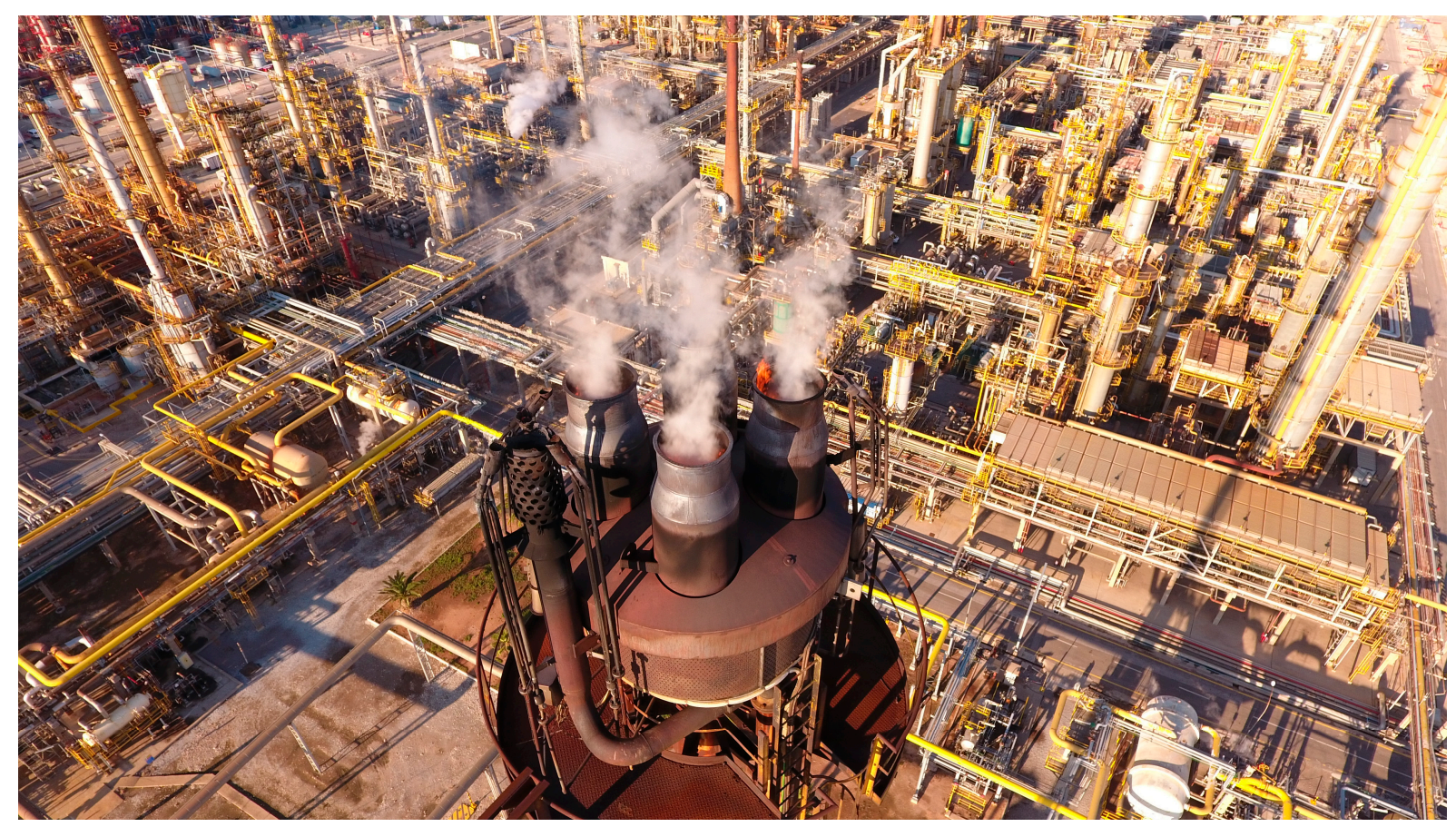

PHOTO 8.2 View from above of a burner in operation using drone inspection 


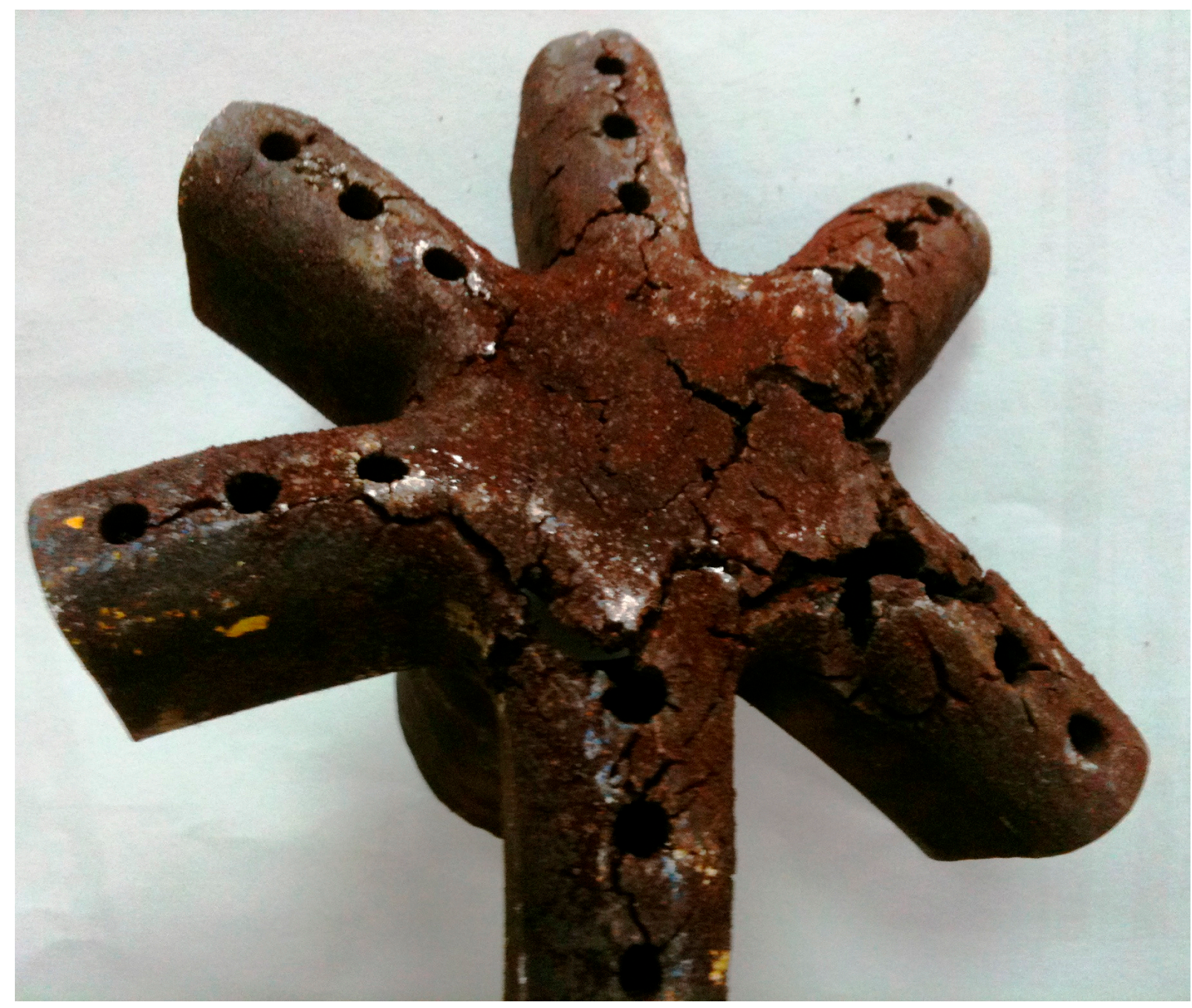

PHOTO 8.3 Image of a nozzle damaged due to high temperatures 


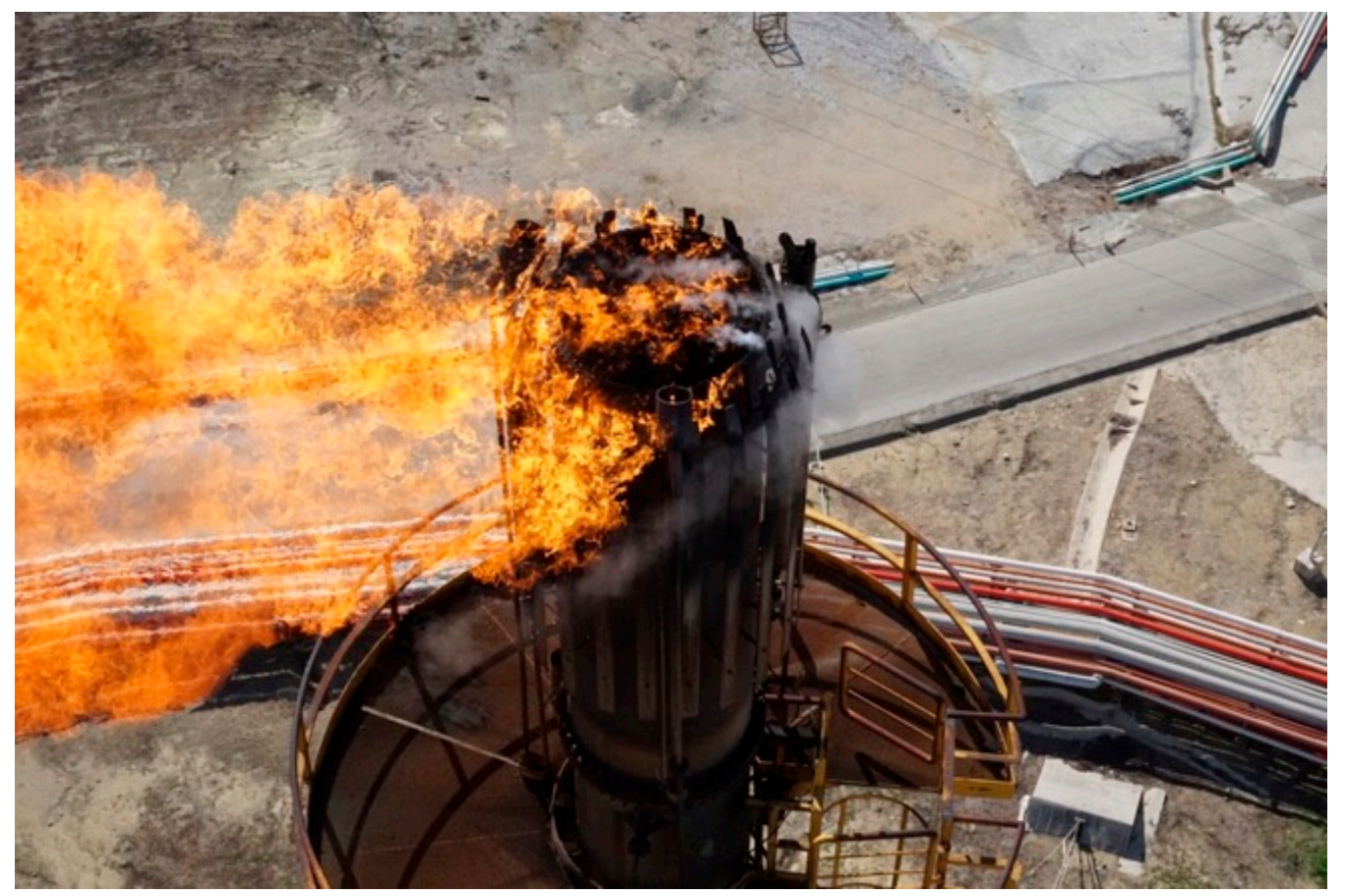

PHOTO 9. Image from above the burner area (tip) of a flare stack with a defect in the steam seal using a drone

\subsection{VISUAL INSPECTION USING DRONES}

Visual inspection using unmanned aircraft has the great advantage of being able to perform the inspection whilst the flare stack is operational, without the need to wait for a stoppage, and additionally cover all the areas of interest of the flare stack mentioned in the previous section. The drone can carry a multitude of cameras and devices, the norm being a powerful camera with $4 \mathrm{~K}$ video recording and optical zoom, which reduces the need to get the drone too close to the flame or other risk areas.

\subsection{INSPECTION USING ULTRASOUND TECHNIQUES}

Ultrasound techniques are used to check the remaining wall thickness both in the shaft and in the pipes that go up to the burner. The shaft is normally divided into three sections coinciding with the guy wires, and measurements are normally taken of the wall thickness every meter; for their part, the pipes are usually measured every meter and at every bend; in both cases rope access techniques allow access to $100 \%$ of the areas of interest. When abnormally low values are detected in the shaft or close to the outlet pipe, it is recommendable to perform a more in-depth inspection of the area in question using ultrasound equipment with a sweep feature, graphical 
representation on a screen and angular probe, to locate any defects with greater precision and determine if they are localised or general.

It should be noted that with carbon steel manufactured before the $80 \mathrm{~s}$, low thickness values caused by manufacturing defects (inclusion of non-metal material that reflects the ultrasonic wave) have been frequently found and should not be confused with internal corrosion processes. To this end, if a visual internal inspection of the shaft should not be possible, $x$-rays would help us to discover the true cause and take the appropriate action.

Research is currently under way (ICDRON, reference???) to analyse the use of drones in these tasks as well, equipping the drones with UT measurement equipment and controllable arms.

\subsection{MAGNETO-INDUCTIVE ANALYSIS OF WIRES}

The magneto-inductive analysis of the guy wires is based on the method of magnetising the wire with permanent magnets, installing a magnetic head on such and moving it along during the test. Irregularities such as loss of metallic area (LMA) and local faults (LF) lead to a redistribution of the magnetic flow around the wire, which is detected by Hall effect sensors [13, 14, 15, 16, 17, 18, 19].

It is recommendable to perform at least two inspection sweeps with the magnetic head along each wire (photo 10), and thus have at least two results sheets per wire, in order to compare these. The rejection criteria are based on the level of average loss of cross-section and the accumulation of local faults within a specific distance; as these are static wires for the supporting of structures, although there is no specific standard for these, the criteria of EN12927-6 [20] or ISO4309 [21] are generally applied, with the additional existence in Spain of UNE 58111-91 [22].

In any case, a prior visual inspection of the wires is recommendable, thus allowing the detection of any broken strands at the surface that would damage the equipment. Following the inspection and analysis of results graphics, if there is an accumulation of local faults, the condition of the damaged area must also be visually confirmed. 


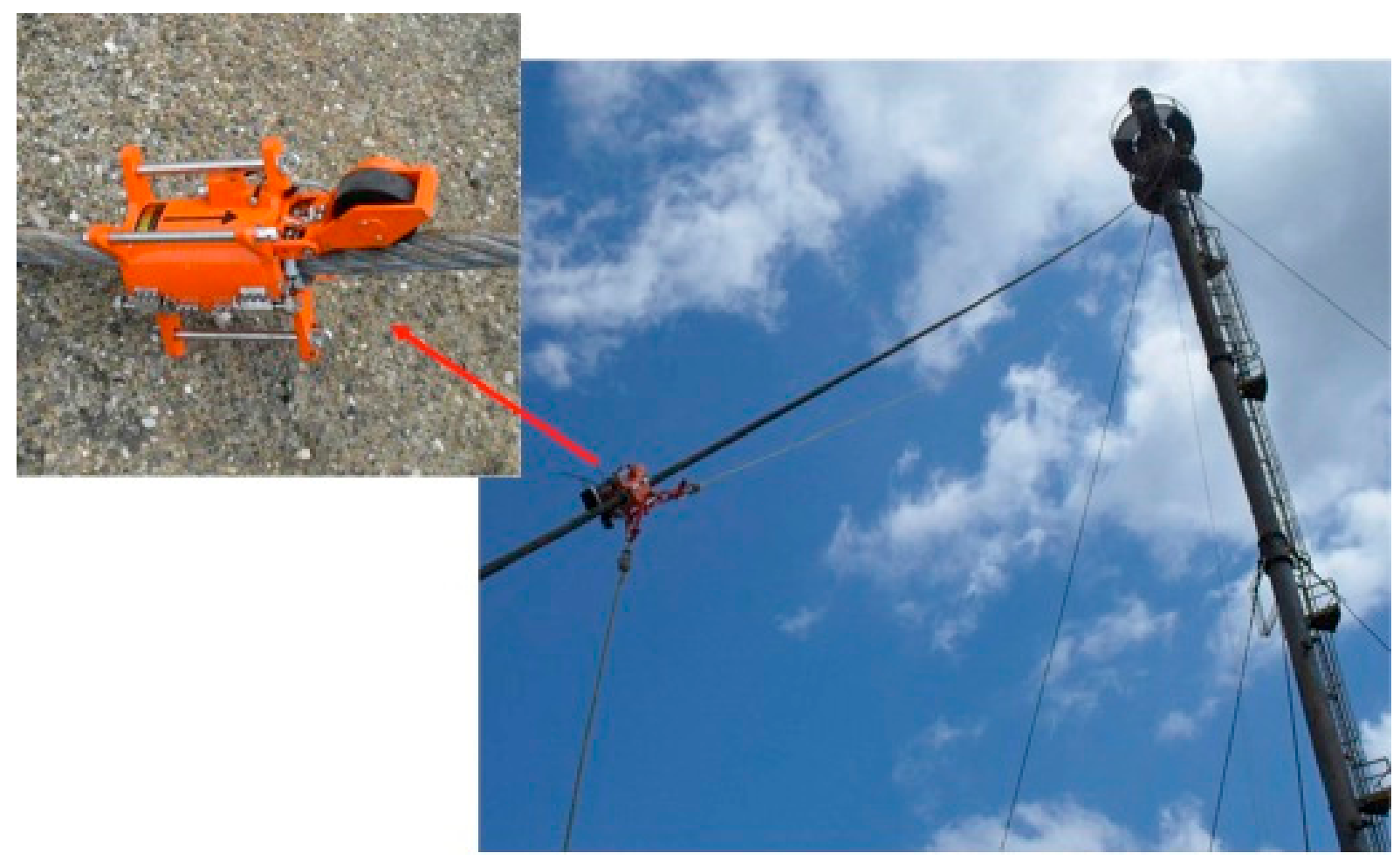

photo 10: Magnetic head for magneto-inductive analysis, moving along the flare stack guy wire

\subsection{MEASUREMENT OF WIRE TENSION}

The guy wires of the flare stack will have the tension indicated on the plans, the normal practice, in the absence of other indications, being to allow a tension of 10 $12 \%$ of the wire tensile strength. The most convenient way to measure the tension of these installed wires is using equipment with load cells, following a preliminary calibration of the diameter and type of wire in question. The modification of the tension values will inevitably lead to variations in the vertical position of the flare stack, which will also be maintained between the recommended values (height/1000 [23]) with the help of topographical means. It is not recommendable to use these tests in parallel with other tests, as the passage of people around the structure will alter the tension values and vertical position.

\subsection{PERFORMING OF X-RAYS}

Industrial gammagraphy is normally used on specific areas as a final check of the shaft thickness levels, when the ultrasound measurements have found areas of low 
thickness in certain areas of the shaft only. An x-ray, as mentioned before, removes any doubt in relation to whether or not the low values are due to manufacturing faults in the steel or if, on the other hand, there is significant internal corrosion. If the area to be $\mathrm{x}$-rayed is not accessible from walkways or ladders, extra precaution must be taken in handling the source due to the risk of this falling, and the application of specific procedures for the handling of radioactive sources at height is recommendable [24]. No other work can take place during the x-ray work; access points must be duly marked with beacons and restricted.

Other NDT techniques such as penetrating liquids or magnetic particles are used sporadically to detect fissures or cracks in specific areas of the flare stack subject to considerable stress, such as, for example, the welds of the lug nuts to anchor the ends of the guy wires.

The decision regarding which techniques to apply in each specific case, as well as the extent thereof, will depend on various factors, namely:

- The time available for the inspection.

- Whether or not faults have been detected visually beforehand (e.g., steam leaks, a change in the colour of the steel of the burners) or during previous inspections.

- Compatibility of NDT techniques to be performed in parallel (see table 1)

- Age of the flare stack

- Available budget

- Planned maintenance work

\section{CONCLUSIONS}

The flare stacks will be inspected regularly to keep these operational and in safe operating conditions. In addition to the use of ladders and platforms, there are various procedures for access and the conducting of said inspections, principally scaffolding systems, elevation platforms and cranes with baskets and access using rope access techniques. The latter allow $100 \%$ of the flare stack to be reached and also reduce the risk, times and cost thereof. In all cases, inspection personnel must be certified according to EN473. With the unstoppable technical development of drones, these are starting to be used as an alternative to traditional visual inspection, with the great advantage of performing the inspection during while the flare stack is operational before the stoppage and thus providing valuable information for the planning thereof and the possible associated repairs.

The NDT techniques most used in the inspection of flare stacks are visual, ultrasound, analysis of variations in magnetic flow and measurement of wire tension, and to a 
lesser degree, $\mathrm{x}$-rays, penetrating liquids and magnetic particles.

As the time available for the inspection of a flare stack tends to be very limited due to the critical nature of this equipment, the selection of the NDT techniques to be applied requires a detailed preliminary study to consider factors such as the stoppage time available, the existence of prior faults and the age of the flare stack. The incompatibility of certain testing techniques with others must also be taken into account, as shown in table 1 , and it should be noted that all of them are very sensitive to adverse weather conditions.

\section{ACKNOWLEDGEMENTS}

The success of the first flare stack inspections carried out using drones for CEPSA (Compañía Española de Petróleos) gave rise to the launching of the ICDRON (InContactDron) three-year project between La Línea Vertical, CEPSA and Dronetools in 2018 with the help of the Advanced Aerospace Technology Centre (CATEC) and cofinanced by the Technological and Industrial Development Centre (CDTI) of the Spanish Government's Ministry of Economy, Industry and Competitiveness.

\section{REFERENCES}

[1] API. "Flare Details for General Refinery and Petrochemical Service". ANSI-API STD 537. $2^{\text {nd }}$ Ed. Washington: API, 2008.

[2] API. "Pressure relieving and depressuring systems". ANSI-API STD 521. $5^{\text {th }}$ Ed. Washington: API, 2007.

[3] Baukal Charles E. "The John Zink Combustion Handbook (Industrial Combustion)". Tulsa, Oklahoma: The John Zink Company, 2001. ISBN: 0-8493-2337-1

[4] CICIND. "Manual for inspection and maintenance of brickwork and concrete chimneys". London: The Signal Press Ltd, 1993. ISBN 1-902998-08-1.

[5] CICIND. Chimney maintenance guide [online]. Zurich: CICIND, 2006. Available on the website:<http://www.cicind.org/EN/files/12-MAINTENANCE-GUIDE.pdf>

[6] CICIND. "A customer's guide for specifying chimneys". Hemel Hepstead, Herts: CICIND, 1990. ISBN: 1- 902998-05-7.

[7] CICIND. "The CICIND Chimney Book, Industrial Chimneys of concrete or steel". Zurich: CICIND, 2005. ISBN: 3-00-017609-8

[8] ANETVA. "Manual de Trabajos Verticales". Madrid: ANETVA, 2006. ISBN: 84-6113678-0

[9] Europe. "European Parliament and Council Directive 2001/45/EC concerning Minimum safety and health requirements for the use of work equipment by workers at work, Annex 4, Provisions concerning the use of work equipment provided for temporary work at a height", Official journal of the European Communities, 19 July 2001, no.195, p48-49. 
[10] Europe. "European Parliament and Council Directive 89/391/EEC concerning Introduction of measures to encourage improvements in the safety and health of workers at work", Official journal of the European Communities, 29 June 1989, no.183, p1-8.

[11] AENOR. "Plataformas elevadoras móviles de personal (PEMP), Cálculos de diseño, criterios de estabilidad, construcción, seguridad, exámenes y ensayos". EN280. Madrid: AENOR 2002.

[12] AENOR. "Ensayos no destructivos. Cualificación y certificación del personal que realiza ensayos no destructivos. Principios generales". EN473. Madrid: AENOR 2009

[13] Sukhorukov V V, Shaparov I I. "Magnetic method for testing tower crane rope terminations: Problems and solutions". In: Proceedings of the OIPEEC Round Table Conference "Rope terminations and fittings". [s.n]. Bethlehem (USA) 2001. ISBN: 07049-2284-1. p.35-46

[14] Sukhorukov V V, Volokhovsky V Yu, Vorontsov A N. "Assessment of steel Rope strength based on non-destructive testing data". In: OIPEEC Bulletin no.82. p.27-33. University of Reading. [s.l] 2001. ISSN 1018-8819

[15] Sukhorukov V V. "Steel Wire Rope Inspection: New Instruments". In: $7^{\text {th }}$ ECNDT. Copenhagen: [s.n.], 1998. ISBN: 87-986898-0-00

[16] University of Reading. "Wire rope non-destructive testing - Survey of Instrument Manufactures". In: UK Health \& Safety Executive. Offshore Technology Report OTO. 2000. [s.l.]: UK Health \& Safety Executive, 2000. p.064

[17] Sukhorukov V V. "Importancia de los ensayos no destructivos de cables". AEND. July 2009. No.49 p.28-36

[18] Tytko A, Kwasniewsky J, Lankosz L. "Non-destructive testing of guy and suspension ropes", In: OIPEEC Technical Meeting, (Kraków, $1^{\text {st }}$ September 1999). [s.n]. [s.l.] 1999. ISBN: 0-7049-1183-3.

[19] ASTM. "Standard Practice for Electromagnetic Examination of Ferromagnetic Steel Wire Rope". ASTM E 1571-06. West Conshohocken: ASTM International, 2006.

[20] AENOR. "Requisitos de seguridad de las instalaciones de transporte por cable destinadas a personas: Criterios de rechazo". EN 12927-6. Madrid: AENOR, 2006.

[21] ISO. "Cranes, Wire ropes, Code of practice for care and maintenance, inspection and discard". ISO4309. Geneva: ISO, 2007.

[22] AENOR. "Cables para aparatos de elevación; criterios de examen y sustitución de los cables". UNE 58111-91. Madrid: AENOR, 1991.

[23] AENOR. "Eurocódigo parte 3. Diseño de estructuras metálicas. Torres, mástiles y chimeneas". EN 1993-3-2:2006. Madrid: AENOR, 2006.

[24] Martín C. "Procedimiento específico para trabajo con manipulación de fuentes radiactivas en zonas de difícil acceso". Cadiz: FORMAL, 2009. 6p.

[25] Spain. "Real Decreto 1036/2017, de 15 de diciembre, por el que se regula la 
utilización civil de aeronaves pilotadas por control remoto [...]", Official State Gazette, 29 December 2017, no.316, p129609-129640.

[26] Martín C., Parrón M.A., "TÉCNICAS DE ENSAYOS NO DESTRUCTIVOS APLICADAS A LA INSPECCIÓN DE ANTORCHAS". DYNA September-October 2013. Vol.88 no.5, p.500505.

\begin{tabular}{|c|c|c|c|c|c|}
\hline $\begin{array}{l}\text { NDT } \\
\text { TECHNIQUE } \\
\text { APPLIED }\end{array}$ & $\begin{array}{l}\text { Level } \\
\text { Training } \\
\text { Inspectors }\end{array}$ & $\begin{array}{l}\text { Cost of } \\
\text { NDT } \\
\text { Equipment }\end{array}$ & $\begin{array}{l}\% \text { Inspection } \\
\text { time (1) }\end{array}$ & $\begin{array}{l}\text { Performing of } \\
\text { other NDT in } \\
\text { parallel }\end{array}$ & $\begin{array}{l}\text { Final technical } \\
\text { cost } \\
\text { NDT }\end{array}$ \\
\hline VISUAL & LOW & LOW & $15 \%$ & NO (2) & LOW \\
\hline ULTRASOUND & AVERAGE & AVERAGE & $25 \%$ & YES & AVERAGE \\
\hline $\begin{array}{l}\text { MAGNETO- } \\
\text { INDUCTIVE } \\
\text { ANALYSIS }\end{array}$ & $\mathrm{HIGH}$ & $\mathrm{HIGH}$ & $35 \%$ & YES & $\mathrm{HIGH}$ \\
\hline $\begin{array}{l}\text { TENSION } \\
\text { MEASUREMENT }\end{array}$ & LOW & AVERAGE & $20 \%$ & NO & AVERAGE \\
\hline GAMMAGRAPHY & $\mathrm{HIGH}$ & $\mathrm{HIGH}$ & $5 \%$ & NO & HIGH (3) \\
\hline DRONES & $\mathrm{HIGH}$ & $\mathrm{HIGH}$ & $0 \%(4)$ & YES & $\mathrm{HIGH}$ \\
\hline Observations & \multicolumn{5}{|c|}{$\begin{array}{l}\text { (1) Analysis applied to a typical flare stack with a height of } 70 \mathrm{~m} \text { and } 12 \text { guy } \\
\text { wires } \\
\text { (2) Areas of the flare stack that have been visually okayed will be accessed } \\
\text { (3) Assuming the area to be x-rayed is not accessible from ladders or } \\
\text { platforms } \\
\text { (4) Can take place during operations before the stoppage }\end{array}$} \\
\hline
\end{tabular}

TABLE 1. Summary of the features of the NDT techniques used in the inspection of flare stacks 